http://jmscr.igmpublication.org/home/ ISSN (e)-2347-176x ISSN (p) 2455-0450 crossref DOI: https://dx.doi.org/10.18535/jmscr/v8i12.02

Journal Of Medical Science And Clinical Research

\title{
To Study the Incidence of Acute Kidney Injury in Patients of COVID-19 Disease admitted in a Tertiary Care Hospital
}

\author{
Authors \\ Dr Anand Kumar Singh", Dr Mukesh Kumar Maurya ${ }^{2 *}$, Dr Rohit Baiswar ${ }^{3}$, \\ Dr Pratyush Kumar \\ ${ }^{1,2,3,4}$ Assistant Professor, Department of General Medicine, M.I.M.S. Barabanki \\ *Corresponding Author \\ Dr Mukesh Kumar Maurya \\ Assistant Professor, Department of General Medicine, M.I.M.S. Barabanki, India
}

\begin{abstract}
Background: In COVID-19 disease, acute respiratory failure and diffuse alveolar damage are common clinical features. Early Symptom include fever, cough and Shortness of breath. Although lungs are the primary organ to be affected by COVID-19, in severe cases other organs can also be affected. Patients admitted with COVID-19, may also have acute kidney damage, some requiring hemodialysis.

Objectives: To study the incidence of AKI in patients of COVID 19 disease.

Methods: An observational study was conducted on 310 patients of COVID 19 disease admitted in a tertiary care hospital.

Results: Out of 310 COVID 19 patients, 227 (73.2\%) were males and 83 (26.7\%) were females. 81 (26.12\%) patients belong to mild, $75(24.19 \%)$ to moderate and $154(37.4 \%)$ to severe COVID 19 disease. Overall AKI was present in $75(24.19 \%)$ patients. In mild disease $8(9.8 \%)$ patients, in moderate disease $14(18.6 \%)$ patients and in severe disease 53 (34.4\%) patients had AKI. Out of 227 male COVID 19 patients, 48 (21.14\%) had mild disease, 63 (27.75\%) had moderate disease and $116(51.10 \%)$ had severe COVID 19 disease. AKI was present in 6 (12.5\%), 12 (19.04\%) and 40 (34.48\%) patients of mild, moderate and severe male COVID 19 disease patients respectively. Out of 83 female COVID 19 patients, $33(39.75 \%)$ had mild disease, $12(14.45 \%)$ had moderate disease and 38 (4578. \%) had severe COVID 19 disease. AKI was present in 2 (6.06\%), 12 (16.66\%) and 40 (34.21\%) patients of mild, moderate and severe female COVID 19 disease patients respectively.

Keywords: COVID-19, Acute Kidney Injury.
\end{abstract}

\section{Introduction}

A number of pneumonia cases of unknown origin emerged in Wuhan, china in early December 2019. The disease had fast spread to other parts of China and globally to many countries ${ }^{1}$. The new causative organism named SARS-COV-2 (Severe Acute Respiratory syndrome corona virus-2) and the resulting illness known as COVID-19 caused a great deal of anxiety and panic worldwide. World Health Organization (WHO) declared it pandemic on March 11, 20202,3. The virus belongs to the same genus as the severe acute respiratory syndrome corona virus (SARS-COV) and Middle east respiratory syndrome corona virus $(\mathrm{MERS}-\mathrm{COV})^{4,5}$. 
In COVID-19, acute respiratory failure and diffuse alveolar damage are common clinical features ${ }^{6}$. Early Symptom includes fever, cough and shortness of breath. The incubation period of COVID-19 seems to be $2-14$ days $^{7}$. According to reports, $81 \%$ of COVID-19 patients in China had mild symptoms while other had severe or critical involvement ${ }^{8-10}$. Although lungs are the primary organ to be affected by COVID-19, in severe cases other organs can also be affected. Patients admitted with COVID-19, may also have acute kidney damage, some requiring hemodialysis ${ }^{11-13}$.Mechanisms of AKI in COVID-19 are microvascular dysfunction, inflammation and metabolic disorders ${ }^{14,15}$. Entry of SARS-COV-2 in human body cells is mediated by ACE-2 receptors ${ }^{16,17}$. ACE-2 receptors is also expressed in the brush border of proximal tubular cells and, up to some extent in podocytes, but not in glomerular endothelial and mesangial cells ${ }^{18}$. During fatal pneumonia due to COVID-19, AKI patients may be affected by synergistic assaults from the virus induced cytopathic effects and systemic inflammatory response, especially in severe and critical cases with positive viral RNA in blood sample and massive proteinuria ${ }^{19}$. In total, renal function of patient hospitalized with COVID-19 infection needs to be monitored regularly to intervene early as possible and to prevent the development of AKI.

\section{Aims and Objectives}

1. To study the incidence of AKI in patients of COVID 19 disease.

2. To study the incidence of AKI in different stages (mild, moderate and severe) of COVID 19 disease.

\section{Materials and Methods}

Study was conducted on 310 patients of COVID 19 disease admitted in a tertiary care hospital.

Type of Study: Observational study.

AKI is defined according to KDIGO 2012 guidelines- an increase in serum creatinine of 0.3 $\mathrm{mg} / \mathrm{dl}$ or more within 48 hours of observation or 1.5 times baseline or greater, which is known or presumed to have occurred within 7 days or a reduction in urine volume below $0.5 \mathrm{ml} / \mathrm{kg} / \mathrm{hr}$. for 6 hours $^{20}$.

Severity (mild, moderate and severe) of COVID 19 disease is defined according to WHO guidelines ${ }^{21,22}$.

\section{Results}

Out of 310 COVID 19 patients, 227 (73.2\%) were males and $83(26.7 \%)$ were females. 81 (26.12\%) patients belong to mild, $75(24.19 \%)$ to moderate and $154(37.4 \%)$ to severe COVID 19 disease.

Overall AKI was present in $75(24.19 \%)$ patients. In mild disease $8(9.8 \%)$ patients, in moderate disease $14(18.6 \%)$ patients and in severe disease $53(34.4 \%)$ patients had AKI.

Out of 227 male COVID 19 patients, 48 (21.14\%) had mild disease, $63(27.75 \%)$ had moderate disease and 116 (51.10\%) had severe COVID 19 disease. AKI was present in 6 (12.5\%), 12 (19.04\%) and 40 $(34.48 \%)$ patients of mild, moderate and severe male COVID 19 disease patients respectively.

Out of 83 female COVID 19 patients, 33 (39.75\%) had mild disease, $12(14.45 \%)$ had moderate disease and 38 (45.78.\%) had severe COVID 19 disease. AKI was present in $2(6.06 \%), 12(16.66 \%)$ and 40 $(34.21 \%)$ patients of mild, moderate and severe female COVID 19 disease patients respectively.

Table 1 Sex-wise distribution of COVID-19 patients

\begin{tabular}{|l|c|c|c|}
\hline $\begin{array}{l}\text { Severity of } \\
\text { COVID-19 } \\
\text { Disease }\end{array}$ & $\begin{array}{c}\text { Number of } \\
\text { Patients }\end{array}$ & \multicolumn{2}{|c|}{ Sex } \\
\cline { 3 - 4 } & & Male & Female \\
\hline Mild & 81 & $48(59.25 \%)$ & $33(40.74 \%)$ \\
\hline Moderate & 75 & $63(84 \%)$ & $12(16 \%)$ \\
\hline Severe & 154 & $116(75.32 \%)$ & $38(24.67 \%)$ \\
\hline
\end{tabular}

Table 2 Incidence of AKI in different stages of COVID-19 Disease

\begin{tabular}{|l|c|c|c|}
\hline $\begin{array}{l}\text { Severity of } \\
\text { COVID-19 } \\
\text { Disease }\end{array}$ & $\begin{array}{c}\text { Stagewise } \\
\text { distribution } \\
\text { of Patients }\end{array}$ & $\begin{array}{c}\text { No of patients } \\
\text { with AKI }\end{array}$ & Percentage \\
\hline Mild & 81 & 8 & $9.8 \%$ \\
\hline Moderate & 75 & 14 & $18.6 \%$ \\
\hline Severe & 154 & 53 & $34.4 \%$ \\
\hline
\end{tabular}


Table-3 Incidence of AKI in male patients

\begin{tabular}{|l|c|c|c|}
\hline $\begin{array}{l}\text { Severity of } \\
\text { COVID-19 } \\
\text { Disease }\end{array}$ & $\begin{array}{c}\text { Number of } \\
\text { male patients }\end{array}$ & $\begin{array}{c}\text { Number of } \\
\text { male } \\
\text { patients with } \\
\text { AKI }\end{array}$ & Percentage \\
\hline Mild & 48 & 6 & $12.5 \%$ \\
\hline Moderate & 63 & 12 & $19.04 \%$ \\
\hline Severe & 116 & 40 & $34.48 \%$ \\
\hline
\end{tabular}

Table 4 Incidence of AKI in female patients

\begin{tabular}{|l|c|c|c|}
\hline $\begin{array}{l}\text { Severity of } \\
\text { COVID-19 } \\
\text { Disease }\end{array}$ & $\begin{array}{c}\text { Number of } \\
\text { female } \\
\text { patients }\end{array}$ & $\begin{array}{c}\text { Number of } \\
\text { female } \\
\text { patients with AKI }\end{array}$ & Percentage \\
\hline Mild & 33 & 2 & $6.06 \%$ \\
\hline Moderate & 12 & 2 & $16.66 \%$ \\
\hline Severe & 38 & 13 & $34.21 \%$ \\
\hline
\end{tabular}

\section{Discussion}

The involvement of kidney in patients with COVID19 is common and can lead to development of acute kidney injury, requiring renal replacement therapy. AKI associated with COVID-19 has high mortality and is independent risk factor for in-hospital death in patients with COVID-19. The pathophysiology of AKI in COVID-19 patients is multifactorial, involving both the direct effects of the SARS-CoV2 virus on the kidney and indirect mechanisms resulting from systemic consequences of viral infections.

Hirsch, J. S. et $\mathrm{al}^{23}$. of 5449 patients admitted with COVID-19 AKI developed in 1993 (36.6\%). The peak stages of AKI were stage 1 in $46.5 \%$, stage 2 in $22.4 \%$ and stage 3 in $31.1 \%$. Of these $14.3 \%$ required RRT. AKI was primarily seen in COVID19 patients with respiratory failure with $89.7 \%$ of patients on mechanical ventilation developing AKI compare to $21.7 \%$ of non-ventilated patients.

Argenziano, M. G. et $\mathrm{al}^{24}$. across all patients in hospital with COVID-19, 33.9\% (288/850) developed AKI and 13.8\% (117/850) required inpatient dialysis. In ICU, AKI and dialysis were even more common at $28 \%(184 / 236)$ and $35.2 \%$ (83/236) respectively.

Pei, G. et $\mathrm{al}^{25}$. On admission, of the 333 patients, $75.4 \%$ (251 of 333) patients had renal involvement, $65.8 \%$ (219 of 333) patients presented with proteinuria, and $41.7 \%$ (139 of 333) patients had haematuria. The incidence of AKI in the overall cohort was $4.7 \%$ (22 of 467) by KIDGO criteria and
$7.5 \%$ (35 of 467) by expanded criteria. A total of $42.9 \%$ (24 of 56) critically ill cases developed AKI during the hospital stay.

In our study, out of 310 COVID 19 patients, 227 (73.2\%) were males and $83(26.7 \%)$ were females. $81(26.12 \%)$ patients belong to mild, 75 (24.19\%) to moderate and $154(37.4 \%)$ to severe COVID 19 disease. Overall AKI was present in 75 (24.19\%) patients. In mild disease $8(9.8 \%)$ patients, in moderate disease $14(18.6 \%)$ patients and in severe disease $53(34.4 \%)$ patients had AKI.

\section{Conclusion}

The new coronavirus (SARS-CoV-2) can cause kidney impairment. The exact mechanism of kidney involvement in COVID-19 infection has not been clarified yet. Until now, there is no specific medication for the cure of coronavirus; hence, the primary solution is supportive care such as preservation of vital signs, regulation of oxygen and blood pressure and reduction complications such as secondary infections or other failures of the organs of the body, including the kidney.

\section{References}

1. Li Q, Guan X, Wu P, Wang X, Zhou L, Tong Y, et al. Early transmission dynamics in Wuhan, China, of novel coronavirus infected pneumonia. N Engl J Med. 2020; 382:1199-207.

doi:

10.1056/NEJMoa2001316.

2. Yang Y, Lu Q, Liu M, Wang Y, Zhang A, Jalali N, et al. Epidemiological and clinical features of the 2019 novel coronavirus outbreak in China. Medrxiv. 2020. doi: 10.1101/2020.02.10.20021675.

3. Huang C, Wang Y, Li X, Ren L, Zhao J, Hu $\mathrm{Y}$, et al. Clinical features of patients infected with 2019 novel coronavirus in Wuhan, China. Lancet. 2020;395(10223):497506.doi: 10.1016/S0140-6736(20)30183-5.

4. Carlos WG, Dela Cruz CS, Cao B, Pasnick S, Jamil S. Novel Wuhan (2019-nCoV) Coronavirus. Am J Respir Crit Care Med. 
2020;201(4):P7-P8.

doi:

10.1164/rccm.2014P7.

5. Rothan HA, Byrareddy SN. The epidemiology and pathogenesis of coronavirus disease (COVID-19) outbreak. J Autoimmun. 2020;109:102433. doi: 10.1016/j. jaut.2020.102433.

6. Naicker S, Yang C-W, Hwang S-J, Liu B-C, Chen J-H, Jha V. The Novel Coronavirus 2019 epidemic and kidneys. . Kidney Int. 2020;97:824-8. doi: 10.1016/j. kint.2020.03.001.

7. Jiang F, Deng L, Zhang L, Cai Y, Cheung CW, Xia Z. Review of the clinical characteristics of coronavirus disease 2019 (COVID-19). J Gen Intern Med. 2020 Mar 4. doi: 10.1007/ s11606-020-05762-w.

8. Chen L, Liu HG, Liu W, Liu J, Liu K, Shang $\mathrm{J}$, et al. Analysis of clinical features of 29 patients with 2019 novel coronavirus pneumonia. Zhonghua Jie $\mathrm{He} \mathrm{He} \mathrm{Hu} \mathrm{Xi} \mathrm{Za}$ Zhi. 2020;43(3):203-208. doi: 10.3760/cma.j.is sn.1001-0939.2020.03.013.

9. Chen N, Zhou M, Dong X, Qu J, Gong F, Han Y, et al. Epidemiological and clinical characteristics of 99 cases of 2019 novel coronavirus pneumonia in Wuhan, China: a descriptive study. Lancet. 2020;395(10223):507-513. doi: 10.1016/S0140-6736(20)30211.

10. Wang D, Hu B, Hu C, Zhu F, Liu X, Zhang $\mathrm{J}$, et al. Clinical Characteristics of 138 Hospitalized Patients with 2019 Novel Coronavirus-Infected Pneumonia in Wuhan, China. JAMA. 2020 Feb7. doi: 10.1001/jama.2020.1585.

11. Guan WJ, Ni ZY, Hu Y, Liang WH, Ou CQ, $\mathrm{He}$ JX, et al. Clinical characteristics of 2019 novel coronavirus infection in China. $\mathrm{N}$ Engl J Med. 2020. doi:10.1056/NEJMoa2002032.

12. Woo PC, Lau SK, Chu CM, Chan KH, Tsoi HW, Huang Y, et al. Characterization and complete genome sequence of a novel coronavirus, coronavirus HKU1, from patients with pneumonia. J Virol.
2005;79:884-95. doi: 10.1128/ JVI.79.2.884895.2005.

13. Song F, Shi N, Shan F, Zhang Z, Shen J, Lu $\mathrm{H}$, et al. Emerging Coronavirus 2019-nCoV Pneumonia. Radiology. 2020; 295(1):210217. doi: 10.1148/radiol.2020200274.

14. Khwaja A. KDIGO clinical practice guidelines for acute kidney injury. Nephron Clin Pract. 2012;120:c179-84.

15. Peerapornratana S, Manrique-Caballero CL, Gómez H, Kellum JA. Acute kidney injury from sepsis: current concepts, epidemiology, pathophysiology, prevention and treatment. Kidney Int. 2019;96(5):1083-99.

16. Kuba K, Imai Y, Rao S, Gao H, Guo F, Guan B, et al. A crucial role of angiotensin converting enzyme 2 (ACE2) in SARS coronavirus-induced lung injury. Nat Med. 2005; 11(8):875-9. doi: 10.1038/nm1267.

17. Zou X. Chen Ke, Zou J, Han P, Hao j, Han $Z$. The single-cell RNA-seq data analysis on the receptor ACE2 expression reveals the potential risk of different human organs vulnerable to Wuhan 2019-nCoV infection. Front Med. 2020 Mar 12. doi: 10.1007/s11684-020-0754-0.

18. Ye M, Wysocki J, William J, Soler MJ, Cokic I, Batlle D. Glomerular localization and expression of angiotensin-converting enzyme 2 and angiotensin-converting enzyme: implications for albuminuria in diabetes. J Am Soc Nephrol. 2006;17(11): 3067-75. doi: 10.1681/ASN.2006050423.

19. Xu H, Zhong L, Deng J, Peng J, Dan H, Zeng $X$, et al. High expression of ACE2 receptor of 2019-nCoV on the epithelial cells of oral mucosa. Int $\mathbf{J}$ Oral Sci. 2020;12;8.

20. The Kidney Disease Improving Global Outcomes (KDIGO) Working Group. KDIGO Clinical Practice Guideline for Acute Kidney Injury. Kidney International Supplements. 2012;2(1):1-138.

21. IMAI District Clinician Manual. Hospital care for adolescents and adults. Geneva: 
World Health Organization; 2020 (https://apps.who.int/iris/bitstream/handle/10 665/77751/9789241548290_Vol2_eng.pdf?s equence $=3$ ).

22. Pocket book of hospital care for children: Guidelines for the management of common childhood illnesses: Second edition. Geneva: World Health Organization; 2013 (https://www.who.int/maternal_child_adoles cent/documents/child_hospital_care/en/).

23. Hirsch, J. S. et al. Acute kidney injury in patients hospitalized with COVID-19. Kidney Int. 98, 209-218(2020).

24. Argenziano, M. G. et al. Characterization and clinical course of 1000 patients with COVID-19 in New York: retrospective case series.

$B M J$

https://doi.org/10.1101/2020.04.20.2007211 6 (2020).

25. Pei, G. et al. Renal involvement and early prognosis in patients with COVID-19 pneumonia. J. Am. Soc. Nephrol. 31, 11571165 (2020). 